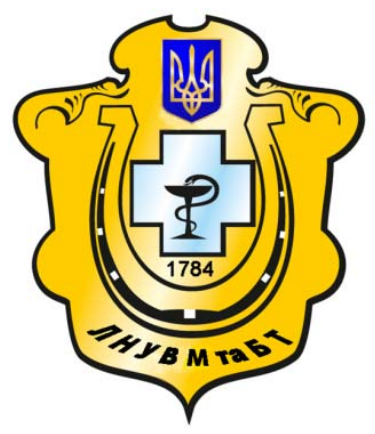

Науковий вісник Львівського національного університету ветеринарної медицини та біотехнологій імені С.3. Гжицького

Scientific Messenger of Lviv National University of Veterinary Medicine and Biotechnologies named after S.Z. Gzhytskyj

doi:10.15421/nvlvet7325

ISSN 2518-7554 print

ISSN 2518-1327 online

$\underline{\text { http://nvlvet.com.ua/ }}$

УДК 619:616-08:619:616.99:636.2

\title{
Вплив клозаверму А та катозалу на показники протеїнсинтезувальної функції печінки корів за експериментального фасціольозу, сенсибілізованих атиповими мікобактеріями
}

\author{
О.В. Куляба, В.В. Стибель, Б.В. Гутий \\ terena4@gmail.com
}

\begin{abstract}
Львівський національний університет ветеринарної медицини та біотехнологій імені С.3. Гюицького, вул. Пекарська, 50, м. Львів, 79010, Україна
\end{abstract}

У статті наведено результати досліджень впливу фасиіольозу та мікобактеріозу показники протеїнсинтезувальноі функиї печінки корів. Фасиіоли і мікобактерії пригнічують протеїнсинтезувальну функиію печінки, на що вказує зниження у їх крові рівня загального протеӥну та альбумінової фракиії. Дані вказують на гепатотропність токсину $F$. hератіса та мікобактерій, адже саме печінка виконує функиію підтримки динамічної рівноваги речовин плазми крові. Підвищення рівня глобулінів у сироватиі крові корів за асоиіації фасиіольозу та мікобактеріозу відображає інтенсивність запальних процесів в організмі тварин викликаних збудниками даних захворювань.

Застосування дослідним коровам клозаверму А та катозалу сприяє відновленню протеїнсинтезувальної функиії печінки. Встановлено, ше після застосування коровам першої дослідної групи для лікування клозаверму А на 14 i 21 доби рівень загального протеїну у сироватиі крові поступово підвищувався, проте не досягав фізіологічних величин. Застосувавщи одночасно клозаверм А та катозал, встановлено дещо вищий рівень загального протеїну, який на 28 добу досліду досягав фізіоло-

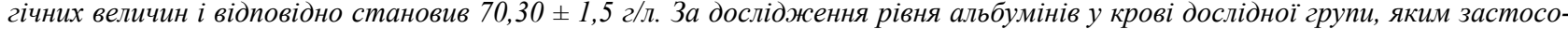
вували препарати поєднано, встановлено його підвищення вже з 7 доби досліду. Вірогідне підвищення рівня альбумінів у крові дослідних тварин спостерігаємо на 14 добу досліду, де відповідно він був у межах 41,90 1 1,5 г/л. На 28 добу досліду рівень глобулінів у крові дослідної групи тварин, яким застосовували клозаверм А та катозал, був нижчим на $11 \%$ відносно контрольної групи тварин у вказаний період досліду.

У корів, яких лікували клозавермом А, величина коефіиієнта А/Г поступово нормалізувалася. Проте, на 28 добу досліду залишалася на 16\% менше від початкових величин, взятих до інвазування. Застосування дослідних тваринам клозаверму $A$ та катозалу сприяло підвищенню величини коефіцієнта А/Г. Так на 21 і 28 доби досліду він був вищим від контрольної групи корів на 60 і $46 \%$.

Ключові слова: мікобактеріоз, фасиіольоз, клозаверм А, катозал, корови.

\section{Влияние клозаверма А и катозала на показатели протеинсинтезирующей функции печени коров за экспериментального фасциолеза, сенсибилизированных атипичными микобактериями}

\author{
О.В. Куляба, В.В. Стибель, Б.В. Гутый \\ terena4@gmail.com
}

Львовский наџиональный университет ветеринарной медицины и биотехнологий имени С.3. Гэникого, ул. Пекарская, 50, г. Львов, 79010, Украина

В статье приведены результаты исследований влияния фасциолеза и микобактериоза на показатели протеинсинтезирующей функиии печени коров. Фасииоль и микобактерии подавляют протеинсинтезируюшую функиию печени, на что

\section{Citation:}

Kulyaba, O., Stybel, V., Gutyj, B. (2017). The influence of closaverm a and catosal on indicators of protein synthesizing functions of cows liver by experimental fasciolosis, sentsitized by atypical mycobacteria. Scientific Messenger LNUVMBT named after S.Z. Gzhytskyj, 19(73), $122-125$. 
указывает снижение в их крови уровня общуего белка и альбуминовой фракции. Данные указывают на гепатотропность токсина F. hератіса и микобактерий, ведь именно печень выполняет функцию поддержания динамического равновесия веществ плазмы крови. Повышение уровня глобулинов в сыворотке крови коров за ассочиации фасциолеза и микобактериоза отражает интенсивность воспалительных процессов в организме животных вызванных возбудителями данных заболеваний.

Применение исследовательским коровам клозаверма А и катозала способствует восстановлению протеинсинтезирующей функции печени. Установлено, что после применения коровам первой опьтной группь для лечения клозаверма А на 14 и 21 суток уровень общего протеина в сыворотке крови постепенно повыпался, однако не достигал физиологических величин. Применив одновременно клозаверм А и Катозал, установлено несколько выше уровень общего протеина, который на 28 сутки опыта достигал физиологических величин и соответственно составил 70,30 \pm 1,5 г/л. 3а исследования уровня альбумина в крови опьтной группы, которым применяли препараты, установлено его повышение уже с 7 суток опыта. Достоверное повышение уровня альбумина в крови подопытных животных наблюдаем на 14 сутки опьта, где соответственно он был в пределах 41,90 $\pm 1,5$ г/л. На 28 сутки опыта уровень глобулинов в крови опьтной группь животных, которым применяли клозаверм А и катозал, был ниже на 11\% относительно контрольной группы животных в указанный период опьima.

У коров, которых лечили клозавермом А, величина коэффициента А/Г постепенно нормализовалась. Однако, на 28 сутки опыта оставалась на 16\% меньше исходных величин. Применение исследовательским животным клозаверма А и катозала способствовало повышению величины коэффициента А/Г. Так на 21 и 28 сутки опыта он был выше контрольной группьл коров на 60 и $46 \%$.

Ключевые слова: микобактериоз, фасциольоз, клозаверм А, катозал, коровы.

\title{
The influence of closaverm a and catosal on indicators of protein synthesizing functions of cows liver by experimental fasciolosis, sentsitized by atypical mycobacteria
}

\author{
O. Kulyaba, V. Stybel, B. Gutyj \\ terena4@gmail.com \\ Lviv National University of Veterinary Medicine and Biotechnologies named after S.Z. Gzhytskyj, \\ Pekarska Str., 50, Lviv, 79010, Ukraine
}

\begin{abstract}
The article contains the results of research the impact of Fasciolosis and mycobacteriosis, the indicators of protein synthesizing function of cows liver. Fasciola and mycobacteria inhibit protein synthesizing function of liver, as indicated by the reduction in their blood level of total protein and albumin fraction. The data indicate hepatotropic of the toxin F. Hepatica and mycobacteria, because namely liver serves as a support of dynamic substances equilibrium of blood plasma. Increasing the level of globulin in the blood serum of cows by association of fasciolosis and mycobacteriosis reflects the intensity of inflammatory processes in animal organism caused by infection of these diseases.

Application of closaverm A and catosal to research cows promotes restoration protein synthesizing function of liver. It was found that after application to cows from the first research group for the treatment of closaverm A by 14 and 21 days of level of total protein in the blood serum was gradually increased, but did not reach physiological values. Applying both closaverm A and catosal, was set a slightly higher level of total protein, that at the 28th day of the experiment reached physiological values and therefore amounted to $70.30 \pm 1.5 \mathrm{~g} / \mathrm{l}$. For the study the level of albumin in the blood of research group, which were used drugs combined, was set its increase already from 7 day of experiment. Significant increase of albumin level in the blood of experimental animals is seeing on the 14th day of the experiment, where appropriate it was within $41.90 \pm 1.5 \mathrm{~g} / \mathrm{l}$. On the $28^{\text {th }}$ day of the experiment the levels of globulin in the blood of experimental group of animals, which were used closaverm A and catosal, was lower by $11 \%$ compared to the control group of animals in specified period of the experiment.

Cows treated with closaverm A, value of the coefficient A/T was gradually returned to normal. However, at the 28th day of the experiment has remained at $16 \%$ less than the initial values, taken before infestation. Application of closaverm A and catosal to experimental animals contributed to increasing the coefficient of A/T. So at 21 st and 28th days of the experiment it was higher than in the control group of cows at 60 and $46 \%$.
\end{abstract}

Key words: mycobacteriosis, fasciolosis, closaverm A and catosal, cows

\section{Вступ}

Серед найбільш поширених патологій паразитарної етіології у жуйних тварин чільне місце за ступенем ураження та заподіяними економічними збитками займають трематодозні захворювання, а саме фасціольоз (Dovgij et al., 2000; Kuljaba et al., 2016). У процесі вивчення епізоотології фасціольозу жуйних важливим $€$ дослідження джерела і чинників передачі інвазії, на що вказують дані літератури (Kuljaba and Stybel', 2015). Основним джерелом інвазії $є$ широке коло дефінітивних живителів, а саме носіїв статевозрілих фасціол, які протягом 5 років можуть інвазувати навколишнє середовище. Зараження жуйних тварин фасціолами відбувається під час поїдання трави 3 низинних та заболочених пасовищ і сінокосів, свіжозібраного сіна й трави, скошеної у таких місцях (Kuljaba et al., 2016). Дощове літо сприяє різкому збільшенню чисельності молюсків у біотопах малого ставковика та кількості заражених фасціолами тварин.

Повідомлення у вітчизняній та зарубіжній літературі також підтверджують те, що, поряд із фасціольозом великої рогатої худоби, значного поширення на- 
був і мікобактеріоз (Dovgij et al., 2000; Kuljaba and Stybel', 2015; Kuljaba et al., 2015). Збудниками мікобактеріозу у тварин $є$ так звані потенційно патогенні мікобактерії (атипові, анонімні або некласифіковані), що характеризуються широким спектром природної лікарської стійкості (Kravciv et al., 2007; Litvinov et al., 2010). До того ж мікобактеріоз зазвичай розвивається тільки в ослабленому організмі тварин, котрі зазнали несприятливого впливу навколишнього середовища чи розвитку різних хвороб, включаючи паразитарні. Попри значну кількість досліджень, які присвячені вивченню фасціольозу у великої рогатої худоби, такі питання, як патогенетичні особливості фасціольозу у корів, сенсибілізованих атиповими мікобактеріями, їх адекватної терапії та профілактики захворювання, потребують поглиблених наукових підходів.

Метою нашої роботи було з'ясувати вплив клозаверму А та катозалу на показники протеїнсинтезувальної функції печінки корів за експериментального фасціольозу, сенсибілізованих атиповими мікобактеріями.

\section{Матеріал і методи досліджень}

Для дослідів було відібрано 15 корів чорно-рябої породи, з яких сформовано 3 групи, по п'ять тварин у кожній. При проведенні досліджень дотримувалися правил, обов'язкових при виконанні зоотехнічних дослідів щодо підбору та утримання тварин-аналогів у групи, технології заготівлі, використання й обліку спожитих кормів. Раціон тварин був збалансований за поживними і мінеральними речовинами, які забезпечували їх потребу в основних елементах живлення.

Тварини контрольної групи були ураженні мікобактеріозом та фасціольозною інвазією. Коровам першої дослідної групи (Д $)$ за експериментального фасціольозу, сенсибілізованим атиповими мікобактеріями, внутрішньом'язово вводили клозаверм А у дозі 0,5 мл препарату на 10 кг маси тіла тварини.

Тваринам другої дослідної групи (Д2), сенсибілізованим атиповими мікобактеріями, за експериментального фасціольозу внутрішньом'язово вводили клозаверм А у дозі 0,5 мл препарату на 10 кг маси тіла тварини та катозал у дозі 10 мл препарату на тварину.
Протеїнсентизувальну функцію печінки визначали за рівнем у сироватці крові загального протеїну (біуретовою реакцією) і протеїнових фракцій (методом електрофорезу в поліакриламідному гелі) (Vlizlo, 2012).

Кров для аналізу брали з яремної вени до зараження та на 7-, 14-, 21 - і 28-у добу досліду.

\section{Результати та їх обговорення}

Протеїни крові тварин, перебуваючи у тісному функціональному зв'язку з білками різних тканин, віддзеркалюють ті зміни, які настають у тканинах і органах організму за розладів у них процесів метаболізму, спричинених патологічними чинниками (Khariv et al., 2016; Hariv and Gutyj, 2016). Саме тому рівень загального протеїну і його фракцій у сироватці крові корів за експериментального фасціольозу, сенсибілізованих атиповими мікобактеріями, відображає білоксентизувальну функцію печінки та ефективність проведеного лікування.

Встановлено, що після застосування хворим коровам для лікування клозаверму А на 14 і 21 доби рівень загального протеїну у сироватці крові поступово підвищувався, проте не досягав фізіологічних величин (табл. 1). На 28 добу досліду рівень загального протеїну крові дослідної групи Д на 7\%. Недостатнє відновлення рівня загального протеїну у корів, що лікували клозавермом А, зумовлено низьким рівнем альбумінів у сироватці крові за ураження мікобактеріозом та фасціольозом. Їх рівень на 14 і 21 добу досліду коливався у межах 39, $17 \pm 1,0-$ $38,20 \pm 1,4$ г/л.

За поєднаного застосування 3 клозавермом А катозалу, встановлено дещо вищий рівень загального протеїну. Так, на 14 і 21 доби досліду у тварин дослідної групи Д 2 він зріс відповідно на 8 і 13\% відносно показників, у корів контрольної групи К. На 28 добу досліду рівень загального протеїну досягав фізіологічних величин і відповідно становив 70,30 \pm 1,5 г/л. За дослідження рівня альбумінів у крові дослідної групи Д 2 , яким застосовували препарати поєднано, встановлено його підвищення вже 37 доби досліду.

Таблиия 1

Вплив клозаверму А та катозалу на показники протеїнсинтезувальної функції печінки корів за експериментального фасціольозу, сенсибілізованих атиповими мікобактеріями $(\mathbf{M} \pm \mathbf{m} ; \mathbf{n}=\mathbf{5})$

\begin{tabular}{|c|c|c|c|c|c|c|}
\hline \multirow{2}{*}{ Показник } & \multirow{2}{*}{$\begin{array}{l}\text { Групи } \\
\text { тварин }\end{array}$} & \multirow{2}{*}{ До зараження } & \multicolumn{4}{|c|}{ Термін досліджень (доби) } \\
\hline & & & 7 & 14 & 21 & 28 \\
\hline \multirow{3}{*}{$\begin{array}{l}\text { Протеїн загальний, } \\
\text { г/л }\end{array}$} & K & $70,12 \pm 1,2$ & $68,04 \pm 1,1$ & $63,72 \pm 1,2$ & $62,22 \pm 1,5$ & $63,93 \pm 1,3$ \\
\hline & $Д_{1}$ & $70,22 \pm 1,0$ & $69,50 \pm 1,5$ & $67,81 \pm 1,6^{*}$ & $66,43 \pm 1,7$ & $68,20 \pm 1,6^{*}$ \\
\hline & $Д_{2}$ & $70,30 \pm 1,3$ & $70,10 \pm 1,7$ & $69,10 \pm 1,4^{*}$ & $70,05 \pm 1,9^{*}$ & $70,30 \pm 1,5^{*}$ \\
\hline \multirow{3}{*}{ Альбуміни, г/л } & $\mathrm{K}$ & $43,40 \pm 1,2$ & $38,16 \pm 1,2$ & $34,47 \pm 1,2$ & $31,15 \pm 1,1$ & $33,66 \pm 1,0$ \\
\hline & $Д_{1}$ & $43,50 \pm 1,0$ & $41,25 \pm 1,5$ & $39,17 \pm 1,0^{*}$ & $38,20 \pm 1,4 * *$ & $39,40 \pm 1,6^{*}$ \\
\hline & $Д_{2}$ & $43,40 \pm 1,2$ & $42,10 \pm 1,4^{*}$ & $41,90 \pm 1,5^{* *}$ & $43,10 \pm 1,2 * * *$ & $43,50 \pm 1,5 * * *$ \\
\hline \multirow{3}{*}{ Глобуліни, г/л } & $\mathrm{K}$ & $26,72 \pm 1,4$ & $29,88 \pm 1,3$ & $29,25 \pm 1,3$ & $31,07 \pm 1,5$ & $30,27 \pm 1,4$ \\
\hline & $Д_{1}$ & $26,72 \pm 1,0$ & $28,25 \pm 1,2$ & $28,64 \pm 1,1$ & $28,23 \pm 1,0$ & $28,80 \pm 1,2$ \\
\hline & $Д_{2}$ & $26,90 \pm 1,1$ & $28,00 \pm 1,4$ & $27,20 \pm 1,3$ & $26,95 \pm 1,1 *$ & $26,80 \pm 1,0^{*}$ \\
\hline \multirow{3}{*}{ Коефіцієнт А/Г } & $\mathrm{K}$ & 1,62 & 1,27 & 1,18 & 1,00 & 1,11 \\
\hline & $Д_{1}$ & 1,63 & 1,46 & 1,37 & 1,35 & 1,37 \\
\hline & $Д_{2}$ & 1,61 & 1,50 & 1,54 & 1,60 & 1,62 \\
\hline
\end{tabular}


Вірогідне підвищення рівня альбумінів у крові дослідних тварин спостерігаємо на 14 добу досліду, де відповідно він був на межі 41,90 $\pm 1,5$ г/л. На 21 і 28 добу досліду рівень альбумінів у крові корів, за експериментального фасціольозу, сенсибілізованих атиповими мікобактеріями, був вищим за показники контрольної групи корів на 38 і $30 \%$.

Як видно 3 даних таблиці 1 у корів за експериментального фасціольозу, сенсибілізованих атиповими мікобактеріями, застосування дослідних препаратів сприяло зниженню рівня глобулінів у крові обох дослідних груп. Так, у крові дослідної групи Д рівень глобулінів на 14 добу досліду становив 28,64 $\pm 1,1$ г/л, тоді як у контролі даний показник становив 29,25 \pm 1,3 г/л. На 28 добу досліду рівень глобулінів був найнижчим, однак не доходив до меж фізіологічних величин.

Рівень глобулінів у крові дослідної групи Д2 37 по 28 доби досліду коливався у межах $28,00 \pm 1,4-$ $26,80 \pm 1,0$ г/л. Починаючи 321 доби досліду рівень глобулінів був у межах фізіологічних величин. На 28 добу досліду рівень глобулінів у крові дослідної групи тварин, яким застосовували клозаверм А та катозал, був нижчим на $11 \%$ відносно контрольної групи тварин у вказаний період досліду.

Важливим показником функціонального стану печінки $є$ величина альбуміно-глобулінового коефіцієнта (А/Г коефіцієнт). Чим він менший від оптимального, тим у більшій мірі зменшена протеїнсинтезувальна функція печінки тварин (Hariv and Gutyj, 2016; Smolynets' et al., 2016).

Як видно з даних таблиці 1 у корів, яких лікували клозавермом А, величина коефіцієнта А/Г поступово нормалізувалася. Проте, на 28 добу досліду залишалася на 16\% менше від початкових величин, взятих до інвазування. Застосування дослідним тваринам клозаверму А та катозалу сприяло підвищенню величини коефіцієнта А/Г, так на 21 і 28 доби досліду він був вищим від контрольної групи корів на 60 і 46\%.

Таким чином, препарати «Клозаверм А» та «Катозал» сприяли відновленню протеїнсинтезувальної функції печінки внаслідок того, що клозаверм А спричинює загибель фасціол. Після звільнення організму від паразитів, припиняється дія їхніх токсинів на печінку та зникають запальні процеси. А катозал, який у своєму складі містить бутафосфан стимулює синтез протеїнів та нормалізує функціонування печінки.

\section{Висновки}

У тварин за експериментального фасціольозу, сенсибілізованих атиповими мікобактеріями, після лікування клозавермом А на 21 і 28 доби не повністю відновилася протеїнсинтезувальна функція печінки. На це вказує низький рівень альбумінів. На наявні запальні процеси вказує підвищений рівень глобулінів. Після вивчення впливу катозалу на протеїнсинтезувальну функцію печінки корів, уражених мікобактеріозом і фасціольозом, встановлено поступову нормалізацію у сироватці крові рівня загального протеїну і його фракцій.

\section{Бібліографічні посилання}

Dovgij, Ju.Ju., Vahovs'kyj, I.L., Semenenko, R.D. (2000). Zahvorjuvannja velykoi' rogatoi' hudoby, vyklykane parazytuvannjam fasciol $\mathrm{v}$ asociacii' $\mathrm{z}$ bakterijamy $\mathrm{i}$ grybamy. Visnyk Derzh. agroekol. akad. Ukrai'ny: Nauk.- teor. zb. -Zhytomyr. 2, 115-118 (in Ukrainian)

Hariv, M.I., Gutyj, B.V. (2016). Influence of the liposomal preparation Butaintervite on protein synthesis function in the livers of rats under the influence of carbon tetrachloride poisoning. Visnyk of Dnipropetrovsk University. Biology, medicine. 7(2), 123-126. doi: 10.15421/021622.

Khariv, M., Gutyj, B., Butsyak, V., Khariv, I. (2016). Hematological indices of rat organisms under conditions of oxidative stress and liposomal preparation action. Biological Bulletin of Bogdan Chmelnitskiy Melitopol State Pedagogical University. 6 (1), 276-289. doi: http://dx.doi.org/10.15421/201615.

Kravciv, R.J., Kuljaba, O.V., Turko, I.B., Semanjuk, V.I. (2007). Osoblyvosti vmistu bilkiv syrovatky krovi tvaryn, kontaminovanyh mikobakterijamy. Naukovyj visnyk L'vivs'kogo nacional'nogo universytetu veterynarnoi' medycyny ta biotehnologij imeni S.Z. G'zhyc'kogo. 9, 4(35), 74-78 (in Ukrainian).

Kuljaba, O.V., Stybel', V.V. (2015). Aktyvnist' enzymiv u syrovatci krovi koriv za fasciol'oznoi' invazii'. Naukovyj visnyk L'vivs'kogo nacional'nogo universytetu veterynarnoi' medycyny ta biotehnologij imeni S. Z. G'zhyc'kogo. 17, 1(2), 41-45 (in Ukrainian)

Kuljaba, O.V., Stybel', V.V. (2015). Stan imunnoi' systemy koriv za asociacii' mikobakterioziv ta fasciol'ozu. Naukovyj visnyk L'vivs'kogo nacional'nogo universytetu veterynarnoi' medycyny ta biotehnologij im. S. Z. G'zhyc'kogo. -17, 2, 309-313 (in Ukrainian).

Kuljaba, O.V., Stybel, V.V., Gutyj, B.V. (2016). The influence of clozaverm $\mathrm{A}$ and catozal on antioxidant status of cows organism for the experimental fasciolosis, sensitized atypical mycobacteria. Scientific Messenger LNUVMBT named after S.Z. Gzhytskyj. 18, 2(66), 96-99. doi:10.15421/nvlvet6621

Kuljaba, O.V., Stybel', V.V., Turko, I.B., Gutyj, B.V. (2015). Metodychni rekomendacii' «Zastosuvannja klozavermu A ta katozalu dlja korekcii' imunnoi' systemy organizmu koriv za fasciol'oznoi' invazii'». L'viv (in Ukrainian).

Litvinov, V.I., Dorozhkova, I.R., Makarova, M.V., Krasnova, M.A., Frejman, G.E. (2010). Vydelenie i identifikacija netuberkuleznyh mikobakterij. Vestnik RAMN. 3, 7-11 (in Russian).

Smolynets', I.B., Gutyj, B.V., Khariv, I.I., Petryshak, O.Y., Lytvyn, R.I. (2016). Pharmaceutical marketing: objectives and types. Scientific Messenger LNUVMBT named after S.Z. Gzhytskyj. 18, 2(69), 151-154. doi:10.15421/nvlvet6929

Vlizlo, V.V. (2012) Laboratorni metody` doslidzhen` u biologiyi, tvary`nny`cztvi ta vetery`narnij medy`cy'ni: dovidny'k. L`viv: Spolom (in Ukrainian).

Стаття надійшла до редакиії 1.03.2017 